\title{
SUPERVISI AKADEMIK KEPALA SEKOLAH DALAM MENINGKATKAN MUTU GURU
}

\author{
Manner Tampubolon \\ Surel : mannertampubolon66@gmail.com
}

\begin{abstract}
One effort to improve teacher professional quality is through academic supervision. The implementation of academic supervision needs to be carried out systematically by the principal, aiming to provide guidance to teachers so that they can carry out their duties effectively and efficiently. The implementation of supervision is not to find fault with the teacher but the implementation of supervision is basically the process of providing assistance services to teachers to improve the teaching and learning process conducted by teachers in improving the quality of learning outcomes. Planned, systematic and directed academic supervision is expected to improve teacher quality. The realization of these goals is not an easy thing. This is because the actualization of the teacher's ability depends on various components of the education system that collaborate with each other. And of course the role of the principal as a supervisor in the school where his assignment must be maximized.
\end{abstract}

Keywords: Academic supervision, Principal, Teacher Quality.

\begin{abstract}
ABSTRAK
Salah satu upaya peningkatan profesional mutu guru adalah melalui supervisi akademik. Pelaksanaan supervisi akademik perlu dilakukan secara sistematis oleh kepala sekolah, bertujuan untuk memberikan pembinaan kepada guru-guru agar dapat melaksankan tugasnya secara efektif dan efisien. Pelaksanaan supervisi bukan untuk mencari-cari kesalahan guru tetapi pelaksanaan supervisi pada dasarnya adalah proses pemberian layanan bantuan kepada guru untuk memperbaiki proses belajar mengajar yang dilakukan guru dalam meningkatkan kualitas hasil belajar. Supervisi akademik yang terencana, sistematik, terarah dan berkesinambungan diharapkan dapat meningkatkan mutu guru. Perwujudan tujuan tersebut bukanlah hal yang mudah. Hal tersebut lantaran aktualisasi kemampuan guru tergantung pada berbagai komponen system pendidikan yang saling berkolaborasi. Dan tentunya peranan kepala sekolah sebagai supervisor di sekolah tempat tugasnya haruslah dimaksimalisasikan.
\end{abstract}

Kata Kunci : Supervisi akademik, Kepala Sekolah, Mutu Guru.

\section{PENDAHULUAN}

Kepala sekolah ditugaskan untuk membawahi para tenaga pendidik dan kependidikan dituntut kepiawaianya dalam mengelola dan mengorganiser lembaga pendidikan yang dijalankanya sehingga apa yang menjadi tujuan pendidikan itu dapat tercapai secara optimal. Kepala sekolah tidak hanya bertanggung jawab atas kelancaran jalanya sekolah secara akademis saja, tetapi juga memikirkan pertumbuhan dan perkembangan sekolahnya, memikirkan hubungan sekolah dengan masyarakat, hubungan guru 
Manner Tampubolon: Supervisi Akademik Kepala Sekolah...

dengan wali murid, dan juga mempunyai wewenang untuk memperbaiki kualitas pendidikan dan mutu para guru di sekolahnya melalui tugasnya sebagai supervisor.

E.Mulyasa, 2003: 111

menuliskan bahwa salah satu tugas kepala sekolah adalah supervisor, yaitu mensupervisi pekerjaan yang dilakukan oleh tenaga kependidikan. Jadi tugas seorang kepala sekolah bukan hanya memimpin sebuah sekolah saja tetapi juga mensupervisi kinerja yang dilakukan guru-guru atau bawahanya di sekolahnya. Kurangnya peran supervise akademik kepala sekolah disebabkan antara lain: a) supervisi dianggap kegiatan formalitas yang harus dilakukan kepala saekolah, b) kegiatan supervisi untuk memenuhi syarat administrasi, c) banyaknya tugas yang dikerjakan kepala sekolah, d) anggapan bahwa guru senior dianggap baik dalam mengajarnya. Secara bahasa supervisi berarti mengamati, mengawasi, atau membimbing kegiatan-kegiatan yang dilakukan oleh orang lain dengan maksud untuk mengadakan perbaikan. Supervisi berasal dari kata "super" artinya lebih atau atas dan "Vision" artinya melihat atau meninjau. Secara estimologis supervisi artinya melihat atau meninjau yang dilakukan oleh atasan terhadap pelaksanaan kegiatan bawahanya (Mukhtar dan Iskandar, 2009: 41). Orang yang berfungsi memebri bantuan kepada guru-guru dalam menstimulir kearah usaha mempertahankan suasana belajar mengajar yang lebih baik yang dapat disebut dengan supervisor.

Menurut ngalim Purwanto, 2005: 76, Supervisi adalah suatu aktivitas pembinaan yang direncanakan untuk membantu para guru dan pegawai sekolah lainya dalam melakukan pekejaan mereka secara efektif. Jadi supervisi merupakan upaya melakukan perbaikan kepala sekolah dalam memberikan masukan dan arahan oleh supervisor, sebagaimana dikutip A. Sahertian, 2000: 17 supervisi adalah suatu usaha menstimulasi, mengkoordinasi dan membimbing secara kontiniu pertumbuhan guruguru di sekolah baik secara individual maupun secara kolektif, agar lebih mengerti danlebih efektif dalam mewujudkan seluruh fungsi pengajaran.

Menurut sergeovani dan starrat pada Mulyasa, 2003: 111, supervisi merupakan suatu proses yang dirancang secara khusus untuk membantu para guru dan supervisor dalam menjalani tugas sehari-hari di sekolah agar dapat menggunakan pengetahuan dan kemampuanya untuk memberikan layanan yang lebih baik pada orang tua peserta didik dan sekolah, serta berupaya menjadikan sekolah sebagai mayarakat belajar yang lebih efektif.

Menurut Suharsini Arikunto, 2004; 5. Dalam bukunya yang berjudul dasar-dasar supervisi akademik adalah supervise yang menitikberatkan pengamatan pada masalah akademik, yaitu yang langsung berada dalam lingkup 
kegiatan pembelajaran yang dilakukan oleh guru untuk membantu siswa ketika sedang dalam proses belajar.

Alfonso, Firt, dan Neville pada Direktorad Tenaga kependidikan, ada tiga konsep pokok dalam pengertian supervise akademik yaitu: a) supervise akademik harus secara langsung mempengaruhi dan mengembangkan perilaku guru dalam mengelola proses pembelajaran. Inilah karakteristik esensial supervise akademik. Sehubungan dengan itu, janganlah diasumsikan secara sempit, bahwa hanya ada satu cara terbaik yang bisa diaplikasikan dalam semua kegiatan pengembangan perilaku guru. Tidak ada satupun perilaku supervisi akademik yang baik dan cocok bagi semua guru. b) perilaku supervisor dalam membantu guru mengembangkan kemampuanya harus didesain secara ofisial, sehingga jelas waktu mulai dan berakhirnya program pengembangan tersebut. Desain tersebut terwujud dalam bentuk program supervisi akademik yang mengarah pada tujuan tertentu. Oleh karena supervisi akademik merupakan tanggung jawab bersama antara supervisor dan guru, maka alangkah baik jika programnya didesain bersama oleh supervisor dan guru. c) tujuan akhir supervisi akademik adalah agar guru semakin mampu memfasilitasi belajar bagi murid-muridnya.

Tujuan umum supervise adalah memberikan bantuan teknis dan bimbingan kepada guru dan staf agar personil tersebut mampu meningkatkan kualitas kinerjanya dalam melaksanakan tugas dan melaksanakan proses belajar mengajar secara operasional. Berikut dapat dikemukakan beberapa tujuan konkrit dari supervisi pendidikan : Meningkatkan mutu kinerja guru yaitu: a) membantu guru dalam memahami tujuan pendidikan dan apa peran sekolah dalam mencapai tujuan tersebut. b) membantu guru dalam melihat secara lebih jelas dalam memahami keadaan dan kebutuhan siswanya. c) membentuk moral kelompok yang kuat dan mempersatukan guru dalam satu tim yang efektif, bekerja sama secara akrap dan bersahabat serta saling menghargai satu dengan lainya. d) meningkatkan kualitas pembelajaran yang pada akhirnya meningkatkan prestasi belajar siswa. e) meningkatkan kualitas pengajaran guru baik dari strategi, keahlian dan alat pengajaran. f) menyediakan sebuah system yang berupa penggunaan teknologi yang dapat membantu guru dalam pengajaran. g) sebagai salah satu dasar pengambilan keputusan bagi kepala sekolah untuk response guru. Meningkatkan kefektifan kurikulum sehingga berdaya guna dan terlaksana dengan baik. Meningkatkan keefektifan dan keefisienan sarana dan prasarana yang ada untuk dikelo9la dan dimanfaatkan dengan baik sehingga mampu mengoptimalkan keberhasilan siswa. Meningkatkan kualitas pengelolaan sekolah, 
Manner Tampubolon: Supervisi Akademik Kepala Sekolah ...

khususnya dalam mendukung terciptanya suasana kerja yang optimal yang selanjutnya siswa dapat mencapai prestasi belajar sebagaimana yang diharapkan. Meningkatkan situasi umum sekolah sehingga tercipta situasi yang tenang dan tentram serta kondusif yang akan meningkatkan kualitas pembelajaran yang menunjukkan keberhasilan lulusan.

Pelaksanaan supervisi akademik yang terpusat pada guru merupakan sasran pokok yang terdapat dalam kegiatan supervisi akademik. Menurut Arikunto, 2004: 33 kegiatan pokok supervise adalah melakukan pembinaan kepada personil sekolah pada umumnya dan khususnya guru, agar kualitas pembelajaranya dapat meningkat. Sebagai dampak dalam meningkatnya kualitas pengajaran dan pembelajaran, diharapkan dapat pula meningkatkan prestasi belajar siswa. Dengan meningkatnya kualitas belajar siswa berarti meningkat pula kualitas lulusan sekolah. Untuk meningkatkan kualitas pengajaran guru maka kepala sekolah perlu melaksanakan pembinaan yang menerapkan prinsip sebagai supervisor.

Menurut Sahertian, 2000: 20. Prinsip-prinsip supervisi tersebut adalah: Prinsip ilmiah yang mencakup unsure-unsur sebagai berikut: a) sistematis yaitu dilaksanakan secara teratur, berencana dan kontiniu. b) objektif artinya data yang didapat berdasarkan pada observasi nyata, bukan tafsiran pribadi. c) menggunakan alat atau instrument seperti angket, observasi, dan percakapan pribadi yang dapat memberikan informasi sebagai umpan balik untuk mengadakan penilaian terhadap proses belajar mengajar. Prinsip demokrasi artinya servis dan bantuan yang diberikan kepada guru berdasarkan hubungan kemanusiaan yang akrap. Demokratis mengadung makna menjunjung tinggi harga diri dan martbat guru, bukan berdasarkan atasan dan bawahan, tetapi berdasarkan rasa kejawatan. Prinsip Konstruktif dan Kreatif. Artinya membina inisyatif guru serta mendorongnya untuk aktif menciptakan suasana dimana setiap orang merasa aman dan dapat mengembangkan potensi-potensinya. Prinsip ini menekankan bahwa kegiatan supervise dilaksanakan untuk membangun dan mengembangkan potensi kreatif para guru. Supervisi diharpkan dilaksanakan dalam suasana yang menyenangkan, bukan menakutnakuti. Dengan demikian para guru lebih termotivasi untuk mengembangkan potensinya.

Selain prinsip diatas Imam Tholkhah dan Ahmad Barizi, 2004: 200. Mengatakan ada empat prinsip supervisi yang perlu diperhatikan oleh kepala sekolah sebagai supervisor akademik yaitu: a) supervisi bersifat korektif. Korektif ini bukan berarti mencari kesalahan, tetapi juga ditemukan kekurangan atau sesuatu kesalahan profesi maka kepala sekolah segera untuk 
memperbaiki dan menyusun rencana atau tata kerja yang lebih baik dimasa-masa selanjutnya. b) supervisi yang bersifat preventif. Kepala sekolah harus bisa mengemukakan kesulitan-kesulitan yang ada dengan rasional sehingga ditemukan jawaban solutif yang mampu mencegah terulangnya kemungkinan kesalahan serupa, supervisi yang sifatnya mencegah kesulitan yang dihadapi, dan berusaha untuk memupuk rasa percaya diri. c) supervisi yang bersifat konstruktif atau mengembangkan wawasan pengetahuan. Kepala sekolah seharusnya senantiasa berusaha membangun kreasi dan imajinasi ke arah pengembangan pendidikan yang lebih baik secara kompetitif. d) supervisi yang bersifat kreatif. Kepala sekolah harus memberikan "rangsangan akademik" kepada semua sivitas sekolah supaya mereka lebih kreatif dan produktif, serta bisa dibangun sikap kerjasama yang baik.

Usaha untuk membantu meningkatkan dan mengembangkan potensi sumber daya guru dapat dilaksanakan dengan berbagai alat dan teknik supervisi. Alat dan teknik supervisi dapat dibedakan dalam dua macam yaitu teknik yang bersifat individual, yaitu teknik yang dilaksanakan untuk seorang guru secara individual. Teknik yang bersifat kelompok, yaitu teknik yang dilakukan untuk melayani lebih dari satu orang. Teknik individual dilakukan dalam bentuk a) kunjungan kelas yaitu kunjungan yang dilakukan dengan

memberitahu, atau tidak memberitahu, tergantung pada sifat tujuan dan masalahnya, kunjungan dapat juga atas permintaan sekolah atau guru yang bersangkutan, dengan memiliki pedoman tentang hal-hal yang akan dilakukan dalam kunjungan tersebut, baik berpa instrument atau catatan-catatan, kunjungan dilakukan dengan tujuan harus sudah cukup jelas. b) observasi kelas; ada beberapa hal yang perlu diperhatikan dalam melakukan obrvasi kelas yaitu observer harus sudah menguasai masalah, tujuan dan sasaran dari observasi yang dilakukan, observasi sedapat mungkin tidak mengganggu kegiatan belajar mengajar, observer sudah menyiapkan instrument atau petunjuk observasi, c) tes dadakan yaitu tes yang diberikan kepada siswa dengan tujuan untuk mengetahui pencapaian target kurikulum dan daya serap siswa sampai pada tes dadakan dilakukan. (Ahmad Azhari: 2004, 5) Teknik kelompok adalah suatu cara pelaksanaan program supervisi yang ditujukan pada dua orang atau lebih. Bentuk teknik yang bersifat kelompok ini, diantaranya yang umum dikenal adalah: Pertemuan orientasi, rapat guru, studi kelompok anatara guru latih, diskusi sebagai proses kelompok, tukar menukar pengalaman (sharing of experience), lokakarya (workshop), diskusi panel, seminar, symposium, demonstrasi mengajar, perjalanan sekolah (Syaful Sagala, 2010: 175). 
Proses supervisi akademik ini dilakukan mulai dari perencanaan, pelaksanaan, pelaporan dan tindak lanjut. Proses tersebut akan dijelaskan sebagai berikut: Perencanaan supervisi akademik. Adapun kegiatan persiapan yang perlu dilakukan adalah mengidentifikasi dan menentukan sekolah-sekolah yang akan disupervisi beserta berbagai permasalahan yang harus diselesaikan pada sekolah tersebut. menyusun program supervise yang mencerminkan tentang adanya jenis kegiatan, tujuan dan saran, waktu, biaya dan instrument supervisi, menyusun organisasi supervise yang mencerminkan adanya mekanisme pelaksanaan kegiatan, pelaporan dan tindak lanjut, dsb. menyiapkan berbagai instrument supervise yang diperlukan (Departemen Agama RI, 2003: 56-57).

Salah satu tugas kepala sekolah adalah merencanakan supervise akademik. Agar kepala sekolah dapat melaksanakan tugasnya dengan baik, maka kepala sekolah harus memiliki kompetemsi membuat rencana program supervisi akademik. Perencanaanprogram supervise akademik adalah penyusunan dokumen perencana pelaksanaan dan rencana pemantauan dalam rangka membantu guru mengembangkan kemampuan mengelola proses pembelajaran untuk mencapai pembelajaran.

$$
\text { Manfaat perencanaan }
$$
program supervisi akademik adalah sebagai berikut,a)sebagai pedoman pelaksanaan dan pengawasan akademik, b) untuk menyamakan presepsi seluruh warga sekolah tentang program supervisi akademik, c) penjamin penghematan serta keefektifan penggunaan sumber daya sekolah (tenaga, waktu, dan biaya). Hal-hal pokok yang perlu mendapat perhatian supervisor dalam melaksanakan supervisi adalah : a) supervisi hendaknya dilakukan pada awal dan akhir catur wulan, b) supervisor bukan mencari-cari kesalahan orang yang disupervisi atau mengguruinya, akan tetapi dalam rangka penilaian dan pembinaan, c) segi-segi yang di supervise mencakup dua hal pokok, yaitu teknis edukatif dan administrative, d) trampil menggunakan dan mengembangkan instrument supervisi pendidikan, e) karena supervisi bersifat pembinaan, maka setiap supervisor hendaknya memiliki kemampuan profesional sebagai Pembina, f) menguasai substansi materi yang akan disupervisi, khususnya kurikulum, PBM dan evaluasi, g) supervisi hendaknya dilakukan secara berkesinambungan, h) Agar pelaksanaan supervisi berhasil dengan baik, maka prinsip kemitraan kerja dengan unsur-unsur yang disupervisikan menjadi sangat penting untuk diperhatikan (Departemen Agama RI, 2003: 57.)

Ada tiga hal penting yang direncanakan dalam pengawasan proses pembelajaran. ketiga hal itu adalah pemantauan, supervisi, dan evaluasi. Perencanaan pemantauan 
direalisasikan dalam bentuk tindakan pemantauan. Tindakan pemantauan dilaksakan sesuai dengan yang direncanakan, cara, tehnik, prosedur, dan instrument yang digunakan mengacu kepada program yang dibuat. Dengan acuan itu setiap aktifitas pemantauan akan dapat dikendalikan dan diukur. Produk atau hasilnya adalah data atau informasi dalam bentuk dokumen, rekaman, atau catatan. Jadi pada dasarnya memantau adalah melaksanakan program pemantauan untuk mengumpulkan informasi atau data yang bertujuan untuk mendapatkan gambaran kondisi rill proses pembelajaran pada suatu pendidikan.

Pelaksanaan pengawasan yang kedua adalah supervisi. Supervisi adalah upaya untuk membantu pendidik memperbaiki dan atau meningkatkan kualitas proses dan hasil pembelajaran. pelaksanaan supervisi terkait dengan hasil pemantauan. Jika hasik pemantauan menggambarkan kondisi yang kurang atau belum baik, maka supervise ditetapkan untuk memperbaiki kualitas proses pembelajaran. pelaksanaan supervise tentu saja mengacu kepada program supervise yang telah disusun. Dengan demikian, tindakan-tindakan dalam supervise akan terlihat sebai tindakan dan terukur secara standar.

Hasil kegiatan supervise adalah terjadinya perbaiakan atau peningkatan. Perbaikan dan peningkatan akan terlihat pada kompetensi pendidik yang bermuara kepada proses dan hasil. Hasil supervisi akan terlihat pada kemampuan atau kompetensi pendidik dalam merencanakan, melaksanakan dan menilai proses/hasil pembelajaran. tolak ukur keberhasilan supervisi berada pada ketiga tataran kegiatan itu yakni peningkatan kemapuan pendidik, dalam merencanakan, melaksanakan, dan menilai proses/hasil pembelajaran. Jadi, pada dasarnya hasil supervise akan terlihat pada proses dan hasil.

Proses dapat diamati pada aktifitas pendidik dan hasil pada produk kerjanya. Pelaksanaan pengawasan ketiga adalah evaluasi. Evaluasi dilakukan terhadap kompetisi pendidik dalam merencanakan, melaksanakan dan menilai proses/hasil belajar. Evaluasi dikaitkan dengan standar nasional pendidikan yakni standar proses dan kompetisi pendidik. Standar proses diatuar dengan peraturan Menteri Pendidikan Nasional Nomor 41 tahun 2007. Apakah perencanaan, pelaksanaan, dan penilaian proses/ hasil pembelajaran telah memenuhi tuntutan standar proses, jika sudah berarti kompetisi pendidik telah terevaluasi dengan benar dan tepat.

Berdasarkan uraian diatas, terlihat bahwa pelaksanaan pengaawasan proses pembelajaran merupakan rangkaian dalam bentuk siklus atau putaran. Pemantauan dilakukan untuk mengumpulkan informasi atau data. Informasi atau data memperlihatkan gambaran nyata proses pembelajaran. dari 
gambaran nyata itu dilakukan supervisi dalam bentuk perbaikan atau peningkatan kualitas proses pembelajaran. hasil supervisi, kemudian di evaluasi, dilihat dengan patron standar proses dan standar kompetisi pendidik. Secara menyeluruh kegiatan pengawasan yang berlangung pada satu periode, ditandai dengan penyusunan program sampai kepada tindak lanjut. Di dalamnya aka nada penilaian, pembinaan, pemantauan, analisis hasil, evaluasi, dan pelaporan.

Penilaian yang dimaksud dalam konteks ini adalah penilaian terhadap pelaksanaan dan hasil supervisi, yang meliputi: a) keterbacaan dan keterlaksanaan program supervisi,b) keterbacaan dan kemantapam instrument, c) permasalahan dalam supervisi edukatif dan administrative, d) hasil supervise, e) volume dan frekuensi kegiatan supervisi. (Depatemen Agama RI, 2003; 58-59 ).

Tindak lanjut adalah bagian terakhir dari kegiatan pengawasan proses pembelajaran. tindak lanjut merupakan jastifikasi, rekomendasi, dan eksekusi yang disampaikan oleh pengawas atau kepala satuan pendidikan tentang pendidik yang menjadi sasaran kepengawasannya. Sedangkan tindak lanjut dari kegiatan supervisi antara lain:a)penyusunan rencana dalam program supervisi,b) langkahlangkah pembinaan,c)perumusan kebijaksanaan pada tingkat pejabat structural baik ditingkat pusat maupun daerah,d) mengamankan data dan informasi sebagai dokumen resmi bagi semua instansi terkait.

Pendidik perlu penguatan atas kompetensi yang dicapainya. Penguatan adlah bentuk pembenaran, bentuk legalisasi,dan bentuk pengakuan atas kompetensi yang dicapainya. Pengakuan seperti ini diperlukan oleh pendidikan, bukan hanya sebagai motifasi atas keberhasilanya, tetapi juga sebagai kepuasan individu dan kepuasan profesional atas kerja kerasnya. Penguatan seperti ini jarang, bahkan hamper tidak diterima oleh pendidik. Penghargaan bagi pendidik yang telah memenuhi standar perlu diberikan. Teguran yang bersifat mendidik diberika kepada guru yang belum memenuhi standar. Teguran dapt dilakukan dengan cara lisan atau tertulis. Idealnya, untuk memenuhin persyaratan administrative, teguran seyogyanya disampaikan secara tertulis. Hal itu akan dapat dipertanggung jawabkan dan dapat pula terdokumtasi. Jika teguran itu berhasil memotivasi pendidik, dokumennya akan bermakna positife baik bagi yang menegur maupun yang ditegur. Jika teguran itu tidak berhasil memotivasi agar pendidik berupaya mencapai standar dalm kerjanya, tentu dapat dilanjutkan dengan teguran berikutnya. Intinya, teguran yang bersifat mendidik adalan teguran yang diharapkan dapat menimbulkan perubahan dan yang ditegur tidak merasa dilecehkan atau tidak merasa tersinggung. 
Tindak lanjut yang terakhir adalah merekomendasikan agar pendidik diberi kesempatan untuk mengikuti pelatihan atau penataran. Rekomendasi itu bukan hanya bermakna bagi pendidik bertugas untuk meningkatkan kinerjanya. Kompetensi supervisi Akademik Kepala Sekolah Dimensi kompetensi supervisi meliputi, merencanakan program supervisi akademik dalam rangka peningkatan kualitas pengajaran guru, melasanakan supervisi akademik terhadap guru dengan menggunakan pendekatan dan tehnik supervisi yang tepat. Serta menindak lanjuti hasil supervisi akademik terhadap guru dalam rangka peningkatan kualitas pengajaran guru. Sedangkan bila mana merujuk kepada permendiknas Nomor 13 tahun 2007 tentang standar kepala sekolah, ada tiga kompetensi supervisi yang harus dimiliki kepala sekolah dalam rangka melaksanakan supervisi akademik sebagai berikut: a) merencanakan program supervisi akademik dalam rangka peningkatan profesionalisme guru, b) melaksanakan supervisi akademik terhadap guru dengan menggunakan pendekatan dan tehnik supervisi yang tepat, c) menindak lanjuti hasil supervisi akademik terhadap guru dalam rangka peningkatan profesionalisme guru.

Uraian diatas mengisyaratkan bahwa kompetisi supevisi akademik adalah suatu aktifitas, kemampuan dalam membina dan menilai para guru dalam melaksanakan proses belajar mengajar. Maka supervisi akademik merupakan pembinaan yang di focus kan untuk meningkatkan kompetensi guru agar mampu meningkatkan kualitas profesinya. Dengan demikian, kompetensi supervisi tersebut perlu diterapkan dalam pelaksanaan supervisi akademik. Simulasi pembelajaran. simulasi pembelajaran, meruoakan suatu tehnik supervise berbentuk demonstrasi pembelajran yang dilakukan oleh kepala sekolah sehingga, guru dapat menganalisa penampilan yang di amatinya sebgai intropeksi diri, walaupun sebenarnya tidak ada mengajar yang paling baik (Mulyasa, 2003; 113-114).

Konsep kepala sekolah sebagai supervisor menunjukkan adanya perbaikam pengajaran pada sekolah yang dipimpinnya, perbaikan ini tampak setelah dilakukan sentuhan supervisor berupa bantuan mengatasi kesulitan guru dalam mengajar. Untuk itulah kepala sekolah perlu memahami program dan strategi pengajran, sehingga ia mampu memberi bantuan kepada guru, yang mengalami kesulitan, misalnya dalam menyusun program dan strategi pengajarannya masingmasing.

\section{SIMPULAN}

Kegiatan supervisi pendidikan sangat diperlukan oleh guru, karena bagi guru yang bekerja setiap hari disekolah tidak ada pihak lain yang dekat mengatasi dan mengetahui diri dalam segala kegiatannya, kecuali kepala sekolah. Guru merupakan 
salah satu faktor penentu tinggi rendahnya mutu hasil pendidikan. Dalam rangka pelaksanaan program supervisi pendidikan maka harus mencakup semua komponen yang terkait dan mempengaruhi terhadap keberhasilan program supervisi pendidikan. Keberhasilan tersebut dilihat dari komponen perencanaan, implementasi dan dampak dari program supervisi pendidikan. Kepala sekolah dalam melaksanakan tugas dan tanggung jawabnya,sebagi supervisor secara efektif, maka kepala sekolah harus memiliki kompetensi yaitu Kompetensi hubungan kemanusiaan, kompetensi manajerial, dan kompetensi teknis.

\section{DAFTAR RUJUKAN}

Arikunto, Suharsimi. 2004. DasarDasar Supervisi. Jakarta: Rikena Cipta.

Azhari, Ahmad. 2004. Supervise Rencana Rrogram Pembelajaran. Jakarta: Rian Putra.

Departemen agama RI Direktorat Jenderal kelembagaan Agama Islam. 2003. Pedoman Pengembangan Administrasi dan Supervisi Pendidikan, Jakarta: Departement Agama RI.

Direktorat Tenaga Kependidikan, Dirjen Peningkatan Mutu pendidikan dan Tenaga kependidikan. Depdiknas. Metode dan Tehnik Supervisi. http://akhmadsudrajat. Wordspress.com/ 2011/03/04/ konsep-supervisi- akademik,h.1. diunduh tanggal 01 mei 2018.

Mulyasa, E. 2003. Menjadi Kepala sekolah profesional. Bandung: PT. Remaja Rosdakarya.

Mukhtar dan Iskandar. 2009. Orientasi Baru Supervisi Pendidikan. Jakarta: Gaung Persada Perss.

Sahertian, piet A. 2000. Konsep Dasar dan Tehnik Supervisi pendidikan dalam Rangka Pengembangan Sumber Daya Manusia. Jakarta: PT. Rineka Cipta.

Tholkhah, Imam dan Ahmad Barizi. 2004. Membuka Jendela Pendidikan, Mengurai Akar Tradisi dan Integrasi Keilmuan Pendidikan Islam Jakarta: PT. Raja Grafindo Persada. 